\title{
Questions of Competence: The Midwife Debate in the Netherlands in the Early Twentieth Century
}

\author{
HILARY MARLAND*
}

In the early decades of the twentieth century a "midwife debate" took place in the Netherlands, in a series of discussions on what the future role of the midwife would be and what tasks she should be allowed to perform. The word "debate" is carefully chosen, for while the exchange became vigorous at times, it never reached the proportions of a "problem" or a "controversy". The Dutch were not concerned with such fundamental issues as registration and control of the profession which dominated the often heated disputes preceding the Midwives Acts of 1902 and 1936 in England. ${ }^{1}$ Such questions had largely been settled, at least on paper. The Dutch debate was in stark contrast to the American "midwife problem", with its sombre consequences for the midwife, the undermining of her economic and professional position, fierce attacks on her abilities, and pressure to oust her from obstetric work. ${ }^{2}$ The importance of the Dutch midwife and her place in obstetric practice as attendant at normal births were not questioned. However, many of the issues raised in the Netherlands dealt directly with the right of the midwife to perform certain obstetric procedures, the division of labour between general practitioners (artsen) and midwives, and potential earning power. The debate was of great significance in consolidating the midwife profession and for the future of obstetric care.

*Hilary Marland, PhD, Instituut Medische Geschiedenis, Erasmus Universiteit Rotterdam, Postbus 1738, 3000 DR Rotterdam, the Netherlands.

This paper was originally presented at the Wellcome Unit for the History of Medicine, Oxford, 8 March 1994, and Science Dynamics, University of Amsterdam, 28 March 1994. I would like to thank the audiences at both talks for their remarks and questions, and Bill Bynum, Godelieve van Heteren, Irvine Loudon, Lara Marks, René Rigter, Rita Schepers, Sister Anne Thompson, and Nanny Wiegman for their constructive comments on earlier versions of this article. I would also like to acknowledge the support of the Wellcome Trust for funding my project on 'Midwives and childbirth in the Netherlands, 1897-1941'.

I Jean Donnison, Midwives and medical men: a history of inter-professional rivalries and women's rights, New York, Schocken, 1977, 2nd ed., 1988; Jean Towler and Joan Bramall, Midwives in history and society, London and New York, Croom Helm,
1986, chs. 7-8; Robert Dingwall, Anne Marie

Rafferty and Charles Webster, An introduction to the social history of nursing, London, Routledge, 1988, ch. 8; and for a reinterpretation of professional models, which links domiciliary midwifery to market forces, Enid Fox, 'An honourable calling or a despised occupation: licensed midwifery and its relationship to district nursing in England and Wales before 1948', Soc. Hist. Med., 1993, 6: 237-59.

2 There is a vast literature on the American midwife problem, including Francis E Kobrin, 'The American midwife controversy: a crisis of professionalization', Bull. Hist. Med., 1966, 40: 350-63; Judy Barrett Litoff, The American midwife debate: a sourcebook on its modern origins, Westport, CT, and London, Greenwood Press, 1986; and for a summary of research to date on American midwives, idem, 'Midwives and history', and Charlotte G Borst, 'The professionalization of obstetrics: childbirth becomes a medical specialty', in Rima D Apple (ed.), Women, health, and medicine in America, New York, Garland Pub., 1990, pp. 435-50, 197-216. 


\section{Hilary Marland}

The involvement of national government with midwife issues began as early as 1818 when the midwife was included in legislation to license medical practitioners and define their tasks. ${ }^{3}$ Though limited by law in what she was permitted to do, supervised by medical committees, and unable to charge as much as doctors for her work, the Dutch midwife did not have to engage in battles to obtain recognition and licensing. ${ }^{4}$ During the 1820 s six clinical schools (klinische scholen) were set up which offered midwife training, though only small numbers took advantage of this. In 1860 state examinations were instituted in response to anxiety about poor standards of obstetric attendance in the countryside. The first state school (Rijkskweekschool) for midwives opened its doors in Amsterdam in 1861, followed in 1882 by a second in Rotterdam. Groningen in the north offered training to a small number of midwife pupils under the auspices of the university medical faculty, and in 1913 a Catholic school opened in Heerlen in the south. Under the 1865 Health Act the midwife's right to act as attendant at normal births was confirmed but limited to this task alone. ${ }^{5}$ Midwives were not allowed to use instruments or to give medicines. The requirement that midwives summon a doctor in drawn-out and difficult cases was also reiterated in 1865 . By the close of the nineteenth century a system of teaching, testing and licensing midwives was firmly in place, and the midwife was recognized as being a proper birth attendanit at normal deliveries. To all intents and purposes it looked as if some form of status quo had been established. ${ }^{6}$

\section{Participants in the Debate}

Yet it was at this point that the discussion on the midwife's place in providing obstetric care gained momentum. This essay will focus on this discussion, turning particularly to the debates in the (Centrale) Gezondheidsraad ((Central) Health Council, the Raad), the government's advisory body on health, ${ }^{7}$ where the main interested parties were able to air their opinions. The discussion concentrated on how the midwife's competence and tasks were to be defined and realized, and was to confirm her central role in Dutch obstetric care.

\footnotetext{
${ }^{3}$ See M J van Lieburg and Hilary Marland, 'Midwife regulation, education, and practice in the Netherlands during the nineteenth century', Med. Hist., 1989, 33: 296-317; Hilary Marland, 'The guardians of normal birth: the debate on the standard and status of the midwife in the Netherlands around 1900', in Eva Abraham-van der Mark (ed.), Successful home birth and midwifery: the Dutch model, Westport, CT, and London, Bergin and Garvey, 1993, pp. 21-44.

${ }^{4} \mathrm{~A}$ basis for national legislation in the nineteenth century was established in town regulations dealing with midwifery practice dating back to the seventeenth century. See H A van der Borg, Vroedvrouwen: beeld en beroep. Ontwikkelingen in het vroedschap in Leiden, Arnhem, 's-Hertogenbosch en Leeuwarden, 1650-1865, Wageningen, Wageningen Academic Press, 1992; Hilary Marland, "The "burgerlijke" midwife: the stadsvroedvrouw of eighteenth-century
}

\begin{abstract}
Holland', in idem (ed.), The art of midwifery: early modern midwives in Europe, London and New York, Routledge, 1993, pp. 192-213, and idem, 'Midwives, age and status in the Netherlands in the eighteenth-century', forthcoming in Hilary Marland and Margaret Pelling (eds), The task of healing: medicine, religion and society in Holland and England, 1450-1800, Rotterdam, Erasmus Publishing, 1995.

$5 \mathrm{~J} J$ Klinkert, Verloskundigen en artsen. Verleden en heden van enkele professionele beroepen in de gezondheidszorg, Alphen a/d Rijn and Brussels, Stafleu, 1980, p. 40.

6 Marland, op. cit., note 3 above.

7 The name of this body changed in 1920 from Centrale Gezondheidsraad to Gezondheidsraad (abbreviated in both cases to Raad). In 1920 the Raad lost its administrative function as head of the public health inspectorate, thereafter acting solely as an advisory body.
\end{abstract}




\section{Questions of Competence: The Midwife Debate in the Netherlands}

A variety of groups and individuals participated in this debate. Midwives took an active part through their own organizations, the Bond van Vrouwelijke Verloskundigen (Society of Dutch Midwives, the Bond) and the Roman Catholic sister societies. ${ }^{8}$ They stimulated much of the debate themselves through their petitions to government, and had much to say about midwife interests in their journal, the Tijdschrift voor Praktische Verloskunde (Journal of Practical Midwifery). A powerful lobby was built up supporting midwives' interests, a mixed bag of politicians, public health officials and doctors, including a number of leading obstetricians. There was limited scope for obtaining support from what was still a very small group of women doctors. ${ }^{9}$ Yet midwives did win the enthusiastic patronage of one of the most influential of this group, Catharine van Tussenbroek. The second woman to enter medical practice in the Netherlands and an eminent obstetrician and gynaecologist, van Tussenbroek proved to be a staunch supporter, angry at what she saw as the lack of credit and reward accorded to Dutch midwives, who were outstanding for their dedication and high standards. ${ }^{10}$

Considerable social distance separated doctors and midwives, and it was only in the 1920s and 1930s, when the costs of training shot up and the status of midwifery as a fit profession for ladies began to be established, that the midwives' schools began to attract girls from well-to-do families. At this point a few midwife leaders began to emerge, including the head midwives of the training schools and prominent Bond activists. By the early twentieth century the majority of Dutch midwives had a school training. Most were the daughters of tradesmen, farmers or craftsmen, a small number obtaining a grant from their province to attend the midwives schools, the remainder being supported by their families. ${ }^{11}$ Compared, for example, with England or the United States, where midwives were a highly diverse group professionally and socially, ranging from the formally trained, including their well-heeled leaders, to the local handywomen or "granny" midwives, there was more unity of background amongst Dutch midwives. This seems to have worked in their favour, and was paralleled by a strong unity of purpose. ${ }^{12}$

General practitioners had a large stake in the outcome of the midwife debate. Since 1865 their right to practise midwifery had been confirmed by law, and by the turn of the century they were delivering over one-third of Dutch babies. Their interest was demonstrated by their role in setting up two reports on midwives' status, practices and

\footnotetext{
${ }^{8}$ For the early years of the Bond, see Floor van Gelder, 'Is dat nu typies vrouwenwerk? De maatschappelijke positie van vroedvrouwen', Tijdschr. Vrouwenstud., 1982, 3: 5-33.

9 Thirteen in 1900,41 in 1910, 125 in 1920 , and by 1930249 . Geneeskundige Jaarboekjes. For women doctors in the Netherlands before 1930, see Hilary Marland, 'Opleiding en carrière van de tweede generatie vrouwelijke artsen in Nederland', Gewina, 1993, 16: 218-33; idem, "'Pioneer work on all sides": the first generations of women physicians in the Netherlands, 1879-1930', forthcoming in $J$. Hist. Med.

${ }^{10}$ Catharine van Tussenbroek, De ontwikkeling der aseptische verloskunde, Haarlem, De Erven F Bohn, 1911, p. 215.
}

\footnotetext{
${ }^{11}$ Hilary Marland, "“A broad and pleasing field of activity"? The payments, posts and practices of Dutch midwives in the early twentieth century', forthcoming in Robert Jütte and John Woodward (eds), Coping with sickness: historical aspects of health care in a European perspective, Sheffield, EAHMH, 1995.

12 Though Catholic midwives were directed towards assisting Catholic mothers and babies, on general issues the Bond and the Catholic midwife societies co-operated closely. The aims of the Catholic Heerlen school are set out in C Meuleman, De Kweekschool voor Vroedvrouwen te Heerlen en de kindersterfte in de zuidelijke provinciën, Heerlen, Moederschapszorg, 1912.
} 


\section{Hilary Marland}

future in 1897 and 1911, which helped further stimulate the debate. ${ }^{13}$ Yet their role in the Raad discussions was limited. The small number of specialist obstetricians carried out little general midwifery work. Neither financially nor professionally did they see midwives as constituting a threat, and a number of them became their firm allies. ${ }^{14}$ Yet they too had a stake in the debate, in ensuring their monopoly over specialized obstetric work and the clinical treatment of cases requiring operative or other medical interventions, and, particularly for the heads of the midwives' schools, in guiding midwife training. Representatives of the health inspectorate were also heavily involved in the debate, especially after 1920 when the role of the midwife in the campaign to reduce infant deaths took a more prominent place alongside other questions of competence. Though it was couched by all parties in terms of public interest, the public rarely entered the midwife debate, which took place largely within the close confines of professional associations, journals and government committees. Women's groups appear to have placed little emphasis on who was carrying out deliveries and how, concentrating instead on a push for improvements in maternity provisions, grants, nursing, infant welfare services and crèche facilities. ${ }^{15}$

\section{The Content of the Dutch Midwife Debate}

In 1897 a report on midwives' standing and future appeared in the Nederlandsch Tijdschrift voor Geneeskunde (Dutch Journal of Medicine). This report, a starting point of the debate, had been collated by the Nederlandsche Maatschappij tot Bevordering der Geneeskunst (Dutch Society for the Promotion of Medicine), an organization representing all doctors, but then largely composed of general practitioners. ${ }^{16}$ The debate continued with ebbs and flows into the middle decades of the twentieth century. ${ }^{17}$ It covered a range

\footnotetext{
13 'Rapport der commissie ter onderzoek naar de wijze waarop door geneeskundigen, verbetering gebracht kan worden in het gehalte en positie der vroedvrouwen in Nederland' (Report of the committee to investigate the means by which medical men can improve the standard and status of midwives in the Netherlands), March, 1897, in Ned. Tijdschr. Geneesk., 1897, 33(1): 610-28; 'Rapport der commissie in zake het vroedvrouwenvraagstuk hier te lande, benoemd door het hoofdbestuur der Nederlandsche Maatschappij tot Bevordering der Geneeskunst in samenwerking met het bestuur der Nederlandsche Gynaecologische Vereeniging' (Report of the commission selected by the Dutch Society for the Promotion of Medicine and the Dutch Gynaecological Society on midwifery practice in the Netherlands), February, 1911, in Ned. Tijdschr. Geneesk., 1911, 55(1): 1105-32.

${ }^{14}$ See Anja Hiddinga, 'Dutch obstetric science: growth and present situation', in Abraham-van der Mark (ed.), op. cit., note 3 above, pp. 45-76, for the development of the specialization of obstetrics.

15 My remark is based largely on the demands of a small number of women's groups who were seeking improvements in maternal and infant care,
}

but much more research is needed on this aspect of women's health provision. See Hilary Marland, 'The medicalization of motherhood: doctors and infant welfare in the Netherlands, 1901-1930', in Valerie Fildes, Lara Marks and Hilary Marland (eds), Women and children first: international maternal and infant welfare, 1870-1945, London and New York, Routledge, 1992, pp. 74-96.

16 Van Lieburg and Marland, op. cit., note 3 above, pp. 306, 311-12.

${ }^{17}$ In different forms, it continues to the present day concerning the precise definition of midwives' tasks, the introduction of new technologies, the place of birth, and discrepancies in the payment of general practitioners and midwives. See, for example, Pieter E Treffers, 'Selection as the basis of obstetric care in the Netherlands', Simone E Buitendijk, 'How safe are Dutch home births?' and Tjeerd Tymstra, 'The impact of medicaltechnological developments on midwifery in the Netherlands', in Abraham-van der Mark (ed.), op. cit., note 3 above, pp. 97-114, 115-28, 129-37; L A $M$ van der Hulst, De vroedvrouw, de spil van de verloskunde, Bilthoven, Catharina Schrader Stichting, 1991. 


\section{Questions of Competence: The Midwife Debate in the Netherlands}

of issues. Various items that might have been expected to feature on the agenda, given what is known of the English and American experiences, were not brought forward for discussion. There was no suggestion of eliminating the midwife, as in the United States. Nor was there talk of significantly reducing or changing her role. The only midwives depicted in sweeping terms as being incompetent, careless or stupid were the old village variety. But some commentators, including many general practitioners, recognized that such midwives still provided a service, given the lack of other alternatives, even if it was far from ideal. A sharp distinction was made between the school-trained midwife and the rest, and concern was expressed about uneven standards and the problem of attracting good candidates to the schools. ${ }^{18}$

Central to the debate was the question of how to deal with the increased and sometimes unfair competition of general practitioners, particularly the younger generation intent on elbowing in on family practice, and the destructive effect of this on midwives' work and earnings. This issue was raised not just by midwives but also by obstetricians wary of the scope of general practitioners' obstetric work. Midwives were also accused by some general practitioners and obstetricians of going beyond the role ascribed to them and "working beyond their abilities". The question of stepping up supervision and control was raised, but unlike in England in the run-up to the passing of the Midwives Acts, this related chiefly to the reporting of difficult cases where midwives had gone beyond their legal competence, or to the possibility of adding more procedures to the midwives' limited armamentarium.

The potential for shifting the place of birth from the home to the hospital-which would have led to increased supervision of the midwife or a decline in her work-was seldom discussed. The situation in other countries, particularly the United States where birth was being rapidly re-routed to hospitals, was noted, but deemed irrelevant to Dutch circumstances. ${ }^{19}$ The normal locus of birth was the home, not the hospital. Some Dutch doctors were even arguing, at a time when only a few thousand women were giving birth in hospital each year, of the dangers inherent in bringing women with complications of pregnancy to clinics, especially from rural areas, which would mean forcing women to travel long distances to deliver their babies. ${ }^{20}$ There was a deeply-felt reluctance on the part of the town authorities, as much as doctors, midwives and mothers, to moving women out of their homes to give birth, no matter how poor they were. A statement made by Rotterdam town council in 1826 declared a sentiment which was still keenly felt a century later: "a maternity ward is absolutely contrary to our national character, and no woman, no matter how humble her descent, should be prepared to put up with a total

\footnotetext{
18 Hilary Marland, 'The midwife as health missionary: between traditional and modern practices in early-twentieth-century Dutch childbirth', paper given at the conference 'Healing, magic and belief in Europe, 15th-20th centuries', Woudschoten, the Netherlands 21-25 Sept. 1994; idem, 'De missie van de vroedvrouw tussen traditionele en moderne kraamzorg in de vroeg 20ste eeuw', forthcoming in Mens en Maatschappij, 1995.

19 By 193537 per cent of U.S. births took place in hospital, by 195088 per cent. In the Netherlands in 1955 over 76 per cent of babies were still
}

delivered at home. Neal Devitt, 'The transition from home to hospital birth in the United States, 1930-1960', Birth and the Family Journal, 1977, 4: 47-58, pp. 47, 56; Klinkert, op. cit., note 5 above, p. 66. For the movement to hospital births in the U.S., see also Judith Walzer Leavitt, Brought to bed: childbearing in America, 1750-1950, New York and Oxford, Oxford University Press, 1986, ch. 7.

${ }^{20}$ P C T van der Hoeven, 'Wanneer moet de zwangere in de cliniek bevallen?', Ned. Tijdschr. Geneesk., 1928, 72(2): 3976-84. 


\section{Hilary Marland}

separation from all her kin and relations . ..". ${ }^{21}$ Reinforced by the domestic and private character of Dutch family life, ${ }^{22}$ which continued to have a strong influence well into the $1960 \mathrm{~s},{ }^{23}$ and the well-developed system of maternity nursing, ${ }^{24}$ a move towards hospital deliveries began to take hold only with the introduction of short-stay "polyclinic" deliveries in $1965 .^{25}$

The number of births in institutions did rise during the early part of the twentieth century, but only nominally, and was limited largely to the most pressing of obstetric emergencies and extreme cases of hardship, including unmarried mothers. Levels of care in the clinics varied, but by the early twentieth century, particularly in those attached to the midwives' schools, conditions were good. With the scandal of the 1860s and 1870s, when Amsterdam's maternity ward was struck by outbreaks of puerperal fever, put behind them, ${ }^{26}$ the emerging group of obstetric specialists established high standards in their clinics, which lacked much of the stigma associated, for example, with Poor Law institutions in Britain. ${ }^{27}$ In the Heerlen school clinic, for example, there was a steady increase in annual admissions from 63 in 1913, to 260 in 1920, and 566 in $1930 .^{28}$ The director of the Catholic Heerlen school, Dr Clemens Meuleman, made a mission of bringing unmarried mothers into the school clinic to give birth. In doing this he claimed he was releasing them from the misery of giving birth in their own communities, where they could be subjected to insult and cruelty, safeguarding their babies, and helping them, through his "rehabilitation centres", to make a new start in life. ${ }^{29}$ Yet by the 1930 s, the purpose of the clinic had changed, with most admissions being for complications of childbirth or gynaecological cases.

Surprisingly little mention was made in the Dutch midwife debate of the good record nationally in terms of maternal mortality, which between 1865 and 1900 had fallen from 87 to 50 deaths per 10,000 births. ${ }^{30}$ By 1920 the maternal mortality rate was 24.2 per 10,000 births compared to 43.3 in England and Wales, 60.9 in neighbouring Belgium, and

\footnotetext{
21 This remark was recorded in the minutes of the Rotterdam town council in 1826 , with reference to the opening of the town's clinical school, where medical students and midwives would have the opportunity to observe deliveries. Cited by $\mathbf{M ~ J}$ van Lieburg, 'Het verloskundig onderwijs aan de klinische school (1826-1867)', in E Scholte, M J van Lieburg and R O Aalbersberg, Rijkskweekschool voor Vroedvrouwen te Rotterdam, Leidschendam, Ministerie van Volksgezondheid en Milieuhygiene, 1982, pp. 21-54, on p. 22.

22 For the central place of the family in childbirth in the Netherlands, see Rineke van Daalen, 'Family change and continuity in the Netherlands: birth and childbed in text and art', in Abraham-van der Mark (ed.), op. cit., note 3 above, pp. 77-94.

23 Johan Goudsblom, Dutch society, New York, Random House, 1967.

${ }^{24}$ E R van Teijlingen, 'The profession of maternity home care assistant and its significance for the Dutch midwifery profession', Int. J. nurs. Stud., 1990, 27: 355-66.

25 In 196074 per cent of deliveries in the
}

Netherlands still took place at home. By 1965 this had fallen to 69 per cent and by 1975 to 44 per cent, Klinkert, op. cit., note 5 above, p. 66.

${ }^{26}$ Maternal mortality rates peaked at 4 per cent in the 1870s. A H M J van Rooy, 'Drie kwart eeuw universitair verloskundig onderwijs te Amsterdam', in Gedenkboek uitgegeven ter gelegenheid van de viering van het vijf en zeventig-jarig bestaan van den Geneeskundigen Kring te Amsterdam, privately printed, 1923, pp. 105-6.

${ }^{27}$ By the 1920s, however, the stigma attached to a Poor Law birth in England was also much reduced. See Lara Marks, 'Medical care for pauper mothers and their infants: poor law provision and local demand in East London, 1870-1929', Econ. Hist. Rev., 1993, 46: 518-42.

${ }^{28}$ It took 25 years, from 1913 to 1938 , before the number of women admitted totalled 10,000 . Out of these, almost half of the first 5,000 were unmarried mothers, only 17 per cent of the second 5,000. Limburgsch Dagblad, 20 June 1938.

${ }^{29}$ De Maasbode, 28 June 1918.

30 Van Tussenbroek, op. cit., note 10 above, p. 212. 


\section{Questions of Competence: The Midwife Debate in the Netherlands}

a massive 79.9 in the United States. ${ }^{31}$ Infant mortality too had fallen continuously since the 1880 s, from 182 per 1,000 in 1881 , to 155 in 1900,108 in 1910 , and by 1920 at 83 per 1,000 the Netherlands had one of the lowest rates in Europe. ${ }^{32}$ Although some commentators, such as van Tussenbroek, saw the midwife as a crucial factor in reducing death rates, the discussion turned less on what had been achieved at a national level than on the enormous regional differentials in maternal and infant death rates.

The rural and largely Catholic provinces in the south of the country offered up a deadly mixture to women in childbed and their infants, composed of poverty, poor housing, filth, and a shortage of maternity nurses and obstetric attendants, both midwives and doctors. From 1901 to 1905 one-fifth of the babies born in North Brabant failed to reach their first birthdays; at 183 per 1,000 live births, the rate in North Brabant was the highest in the country, with Limburg coming a close second with 173 , compared with a national rate of 136 and 92 per 1,000 in the prosperous, urbanized area of South Holland. ${ }^{33}$ More stillborn babies were born in the two provinces than anywhere else in the country, a massive 13 per cent of the babies delivered by doctors in Limburg, 7 per cent in North Brabant in 1906, compared with a national rate of 5 per cent. ${ }^{34}$ Since the late nineteenth century, there had been a push, particularly from the region itself, to improve obstetric services and coverage in the south, in particular to attract well-trained midwives to poor rural areas. ${ }^{35}$ Coupled with this was the problem of unqualified practice, how to get rid, particularly in country areas, of the "dorps" (village) midwife, and her associates, the "bakers", unqualified maternity nurses, and grannies and neighbours, when there was no one with which to replace them. ${ }^{36}$ The proportion of births delivered by unqualified personnel was declining, but it was seen as a persistent problem for the authorities. ${ }^{37}$ At a time of rising concern about infant mortality, when various forms of all-embracing care systems for

31 Irvine Loudon, 'Maternal mortality: 1880-1950. Some regional and international comparisons', Soc. Hist. Med., 1988, 1: 183-228, p. 186. Irvine Loudon's international comparisons suggest that the well-trained Dutch midwife contributed to the country's low rates of maternal and perinatal mortality. Irvine Loudon, Death in childbirth: an international study of maternal care and maternal mortality 1800-1950, Oxford, Clarendon, 1992, pp. 415-21.

32 B R Mitchell, European historical statistics 1750-1970, London, Macmillan, 1975, pp. 40-1, 43.

${ }^{33} \mathrm{C}$ Vandenbroeke, $F$ van Poppel and $A M$ van der Woude, 'De zuigelingen en kindersterfte in België en Nederland in seculair perspectief', Tijdschr. Gesch., 1981, 94: 461-91, p. 481.

34 Van Tussenbroek, op. cit., note 10 above, pp. $187,189$.

35 Inequalities in obstetric services paralleled those in other categories of health care and great variations in regional death rates, with the southern Catholic provinces tending to come out worst. See Frans van Poppel, 'Religion and health: Catholicism and regional mortality differences in nineteenthcentury Netherlands', Soc. Hist. Med., 1992, 5:
229-53; R Philips, Gezondheidszorg in Limburg. Groei en acceptatie van de gezondheidsvoorzieningen 1850-1940, Assen, Van Gorcum, 1980.

36 Cf. Molly Ladd-Taylor, "“Grannies" and "spinsters": midwife training under the SheppardTowner Act', J. soc. Hist., 1988, 22: 255-75.

37 Again there were great regional variations, and rates tended to be much higher in rural areas. In 1906 one estimate claimed that nationally 5 per cent of women gave birth without qualified assistance, but in Groningen the rate was almost 20 per cent and in North Brabant 13 per cent. In the province of North Brabant only half of the midwives listed as being in practice in 1899 had attended a training school, by 192077 per cent. Van Tussenbroek, op. cit., note 10 above, pp. 183, 185; Marga Pruijt, 'Roeien, baren en in de arbeid zijn. Vroedvrouwen in Noord-Brabant, 1880-1960', in Maria Grever and Annemiek van der Veen (eds), Bij ons moeder en ons Jet. Brabanste vrouwen in de 19de en 20ste eeuw, Zutphen, Walburg, 1989, pp. 122-42, on p. 129. See also, for North Brabant's midwives, Marga Pruit, 'De verloskundige zorg in Noord-Brabant, 1918-1940', Social Wetenschappen, 1988, 31: 175-93. 


\section{Hilary Marland}

mothers and babies were being advocated, many mooted the recruitment of the midwife as a first-line defence in the campaign to reduce infant deaths.

The other question to be raised repeatedly throughout the midwife debate was how far the midwife's competence to perform obstetric procedures should be extended, if at all. It was a cornerstone of the discussions in the government's advisory council on health, the (Centrale) Gezondheidsraad. The law of 1865 had restricted midwives' use of medicines and instruments to administering catheters and enemas. By the early twentieth century, deeming the law irrelevant, midwives and their supporters were demanding the right to give injections and medicines to speed up the delivery and to expel the placenta, to intervene in cases of bleeding or spontaneous abortion, to stitch tears of the perineum, to use pain relief, and to apply forceps. Also discussed was the length of midwives' training, whether it should be altered, improved or added to, and to what extent learning should be matched to practice, for midwife pupils were schooled to a level which went far beyond what they were allowed to do in practice. ${ }^{38}$

The discussions had a wide significance. The issue of making the supervision of healthy infants the work of the midwife, for example, would extend the midwife's role far beyond attendance at normal births. It also raised important and emotive questions concerning the respective duties, accountability and pecking order of doctors, midwives and nurses. Many doctors vigorously opposed such a move, fearing that the midwife was not sufficiently trained to recognize illness in babies; many simply feared a loss of influence and income. Supporters of such an extension of the midwives' role argued that it would be no harder to teach midwives to recognize a sick infant than to detect abnormalities of pregnancy or childbirth; it was simply an natural extension of the work of midwives who had attended the mother, visited her after the birth, and who were familiar with the home situation. ${ }^{39}$ It was also suggested by some doctors that in regions where the midwife had difficulty supporting herself through midwifery work alone, adding the extra responsibility of infant care would enable midwives to generate enough income to survive in practice. So, the question of giving the midwife responsibility for infant welfare became closely linked to that of providing good obstetric coverage.

The tone of the midwives' debate was far milder in the Netherlands than elsewhere. Yet its implications should not be underestimated. Questions of competence linked up with questions relating to competition with doctors, choices for clients, and challenged the midwife's profile and raison d'être. The midwife took risks in demanding more competence, for if she was to take on board new interventionalist techniques and new tasks, she could be accused of abandoning her role as "guardian" of, and specialist in, normal births. Midwives and their supporters expressed concern that they would lose out

\footnotetext{
38 The two year course was extended to three years in 1921, and, despite a massive extension in the syllabus, remained fixed at three years until 1994 when an extra year was added. Pupils to the schools obtained an extensive grounding in anatomy, physiology, special knowledge of the "female parts", theoretical and practical midwifery, and nursing. The textbooks, several of which were written by the school directors, were demanding. The pupils, many with limited schooling, were also brought up to scratch in the three Rs. The drop out rate was high,
}

many pupils had to re-take a year, and in some years more than half the pupils failed the examination. See, for the Rotterdam school, M J van Lieburg, 'De Rijkskweekschool voor Vroedvrouwen (1882-1926)', in Scholte, van Lieburg and Aalbersberg, op. cit., note 21 above, pp. 55-96. In England, by comparison, midwife training was doubled in length during the First World War from three to six months, and for qualified nurses four months.

${ }^{39}$ Nieuwe Rotterdamsche Courant, 3 Dec. 1920. 


\section{Questions of Competence: The Midwife Debate in the Netherlands}

to the doctor if not allowed to use techniques to reduce pain and speed delivery. At the same time, midwives also argued that an extension of their competence would ensure that deliveries remained as "normal" as possible, freeing them from having to call in a doctor to intervene, often at a critical and dangerous time, enabling them to do their job "fully" and "properly". The outcome for the women they attended and their babies would simply be better and safer.

\section{The (Centrale) Gezondheidsraad as Forum}

In 1902 the Centrale Gezondheidsraad was set up to head and administer the public health inspectorate and to act as the government's advisory body on health. It is the Raad's advisory functions that are the concern of this essay. Made up of permanent members, representatives of professional groups and invited experts, the Raad was commissioned by the government to make recommendations on health matters as wide ranging as water purity, epidemic disease control and unqualified medical practice to the impact of séances, additive-free coffee and the heating of train compartments. The advice of the Raad was requested on many occasions. It produced reams of recommendations, not necessarily followed, but more than enough to make it a highly influential body. ${ }^{40}$ It was to be crucial to the midwife debate, the government turning to the Raad for advice on many questions connected to midwives' training and work. The government's decision to consult the Raad was often based on a letter or petition from a pressure group or individual, and the midwives, through their society, were regular petitioners. The referral of these petitions to the Raad is a measure of the seriousness with which midwives' grievances were taken, as well as the unwillingness of the Dutch government to act or intervene unsupported by expert opinion in health care matters.

The membership of the various committees set up to deal with midwives' issues under Raad auspices represented diverse and sometimes conflicting interests, which could be based on regional differences, particularly the north/south, Protestant/Catholic divide, or political divisions between liberals and conservatives. Its members consequently held a wide range of opinions on health matters, including the position of the midwife and her role in obstetric services. The experts who were co-opted on to Raad committees, either serving as full members or offering ad hoc advice, included the directors of the midwives' schools, the four professors of obstetrics and gynaecology, infant welfare campaigners, and representatives of professional organizations. The midwives had their own voice on the Raad, in the person of Mej. Sievertsen Buvig, a Bond activist and chief midwife at the Amsterdam midwives' school. ${ }^{41}$

The Raad was only one platform in the midwife debate, albeit an important one. But, partly because general practitioners were not well represented, the Raad debate may distract attention away from the rawer aspects of the midwife question and the realities of practice. Parallel to the Raad discussions, in the country's towns and villages general

40 In his recent thesis on the Gezondheidsraad, René Rigter has made the claim that advice was followed in 70 per cent to 90 per cent of cases. René Rigter, Met raad en daad. De geschiedenis van de Gezondheidsraad 1902-1985, Rotterdam, Erasmus Publishing, 1992.

\footnotetext{
${ }^{41}$ She was also the author of a useful history of the Amsterdam school, S Sievertsen Buvig, Geschiedenis van de Rijks Kweekschool voor Vroedvrouwen te Amsterdam van 1861 tot 1921, Amsterdam, Rijkskweekschool voor Vroedvrouwen, 1921.
} 


\section{Hilary Marland}

practitioners and midwives struggled to make their way in practice, competing openly with each other over posts and patients. A number of highly publicized cases were recorded in the medical press and midwives' journal, the Tijdschrift voor Praktische Verloskunde, such as the Uitgeest case of 1901, when a doctor was appointed "town midwife" by the local council in the midst of protests from the midwives' Bond and from Dr Niemeijer, editor of the midwives' journal. ${ }^{42}$ Even so, the Raad drew together a wide cross-section of opinion, if not in equal proportions, and it presented a more finely nuanced and broadly-based debate involving those not necessarily affected in practice or financial terms by the debate's outcome.

Even a single group of experts could express very different views, and minority opinions were recorded alongside the recommendations of the Raad. Though broadly agreed in their purpose of producing well-trained midwives, the interests and ideas of the three directors of the midwives' schools at Amsterdam, Rotterdam and Heerlen, for example, often differed, sometimes to the point of open argument. All were influential in Raad discussions. All were men of strong, even extreme, opinions. But their characters, background and visions of the role of their schools were very different. Klaas de Snoo, an influential though controversial figure in obstetrics, headed the Rotterdam school from 1907 to 1926, when he was appointed professor of obstetrics in Utrecht. He was responsible for introducing rigorous theoretical teaching to the Rotterdam school and wrote a textbook, the Beknopt leerboek der verloskunde (1910), intended to train the next generation of midwives. ${ }^{43}$ While encouraging ever higher standards and more demanding courses-also, not noted for his modesty, dedicating special times for the daily study of his own book-de Snoo believed in maintaining a strict division of obstetric labour. An irascible individualist, his lack of interest in the opinions of others became all too apparent in Raad discussions, where he energetically opposed extending midwives' competence.

Dr R J Th Meurer, head of the Amsterdam school, meanwhile, bordered on the radical when it came to the question of midwives' competence. Appointed as director in 1898, he welcomed the addition of a third year's teaching in 1921 as a golden opportunity to teach pupils more with a view to letting them undertake a wider range of procedures in practice. The two other directors took a gloomy view of this, seeing the third year as providing the chance to ground their pupils thoroughly in infant hygiene and to go over old material again. In 1925 Meurer recommended extending midwives' competence in ways that even midwives themselves, at this point, had rarely suggested, to include giving pituitrin injections to speed labour, perhaps also camphor and morphine for pain relief, "while the ban on applying forceps in some, very special cases, could be controlled less strictly". He also believed that midwives should be allowed to treat thrombosis and toxaemia and to repair ruptures. Not all midwives were equipped to carry out these procedures, Meurer concluded, but refresher courses would adequately prepare them for these extra tasks. ${ }^{44}$

42 Tijdschrift voor Praktische Verloskunde, 1901, 5: 161-5, 177-9. See Marland, op. cit., note 11 above.

${ }^{43}$ For the period of de Snoo's directorship of the Rotterdam school, see van Lieburg, op. cit., noţe 38 above, pp. 82-8.

\footnotetext{
44 Archief Vroedvrouwenschool Heerlen (AVH), 1b. Vergaderstukken van de Gezondheidsraad, 1920-30. R J Th Meurer, 'Rapport inzake herziening van de bevoegdheid der vroedvrouwen', Dec. 1925, quote p. 4 .
} 


\section{Questions of Competence: The Midwife Debate in the Netherlands}

By law the midwife was prohibited from carrying out these procedures, and Meurer's recommendations aroused the fury of de Snoo, who drew up a reply explaining in great detail why midwives' competence should not be extended. "Amice” Meurer was accused of going behind the backs of the other directors in making the Raad aware of his opinions. Nothing, de Snoo argued, had changed through the addition of an extra year's schooling; a midwife was a midwife, not a doctor, and should not carry out the doctor's work. On the question of pituitrin, de Snoo found it "in the hands of the doctor, who is in a rush, a dangerous thing and thus also in the hands of the midwife in general". De Snoo believed that all cases of thrombosis were caused by infection, and concluded that women with symptoms should be isolated; in the Rotterdam school the pupils were not allowed to come into contact with such patients. ${ }^{45}$ Yet, unusual and outspoken as de Snoo's opinions were, in one remark he captures the essence of the debate:

For normal midwifery I would chose the midwife before the doctor, not because she knows better what there is to offer, or because she carries out her work with more love, but because her competence is limited, through which the natural process of labour under normal conditions is better guaranteed. ${ }^{46}$

Dr Clemens Meuleman, head of the Heerlen school between 1913 and his death in 1932, appears to have been less interested in the finer issues of competence, but he was very concerned to have midwives involved in infant hygiene. The Heerlen school aimed to provide midwives for North Brabant and Limburg, where more mothers gave birth without a midwifery attendant than anywhere else in the country. ${ }^{47}$ The campaign to set up a school in the south to train local girls in midwifery dated from late in the nineteenth century. ${ }^{48}$ It had stimulated a good deal of opposition, which explains why the campaigners failed in their aims until 1913, when a school was finally set up under the auspices of the Catholic society Moederschapszorg (Motherhood care). In 1902 the question of setting up a third school had been referred to the Raad. Many Raad members argued that an additional school would lower overall standards of admission and training. The midwives' society, the Bond, agreed, opposing such an initiative on the grounds of over-production and competition. Dr Woltering, chief health inspector for the southern provinces and a Catholic, however, argued in a minority note to the Raad that possibly standards would be lowered overall, but that the level of obstetric practice in the region would be improved, and that expectations were lower in the south in any case. ${ }^{49}$ When the school was set up in 1913 director Meuleman's aims were to train good Catholic midwives to deliver Catholic mothers, to help unmarried mothers deliver their babies safely, to improve standards of infant care and reduce mortality rates, and to provide midwives for the colonies. This is not to say that the other directors had no interest in such issues, but for Meuleman, also reflecting local sentiments, his own strong Catholicism, and the very real backwardness of the region in terms of obstetric services, these took precedence. ${ }^{50}$

\footnotetext{
45 Ibid., Afschrift, Brief van de Snoo aan Meurer, 23 Dec. 1925, pp. 1-2, 6, 8.

46 Ibid., p. 3.

${ }^{47}$ Meuleman, op. cit., note 12 above, pp. 1-2.

$48 \mathrm{~J}$ H Starmans, Verloskunde en kindersterfte in Limburg. Folklore: Geschiedenis: Heden, Maastricht, Van Aelst, 1930, pp. 143-61.
} 


\section{Hilary Marland}

\section{The Muted Impact of the Centrale Gezondheidsraad 1902-20}

During the opening years of the twentieth century the Centrale Gezondheidsraad was drawn increasingly into midwives' issues. Yet the Raad showed little initial interest in the wishes of midwives, as expressed by the Bond van Vrouwelijke Verloskundigen. In 1904 the Bond's committee wrote to the minister of internal affairs making a plea for a clarification of midwives' role and an extension of their competence. They demanded the right to use forceps, to repair perineal tears, and to give help in cases of spontaneous abortion. ${ }^{51}$ The demands were referred to the Raad, who in March 1905 reported that midwives should only assist at births with an "untroubled natural progress", and lacked the "vital knowledge and general development" to extend their competence. The Raad believed any extensions of competence would constitute a "very great danger". In the case of abortion midwives were not qualified to give a precise diagnosis. ${ }^{52}$ The Raad recommended that the government act more strongly against unqualified practitioners, but overall they put little effort into assessing the viability of the midwives' demands. In the same year, the Raad was made responsible for drawing up a brochure entitled 'Information and advice to the midwife on the practice of her work' ${ }^{53} \mathrm{~A}$ rather dull and non-committal pamphlet, it summed up the midwife's duties, instructed her on her oath, on hygiene and care of the newborn's eyes, and gave tips to those starting out in practice, including a list of things she would need: nail brushes, dressings, sterilizing equipment, and a clean, white apron. ${ }^{54}$

In 1910 events took a similar course. In an address to the minister for internal affairs, signed by over 300 midwives, two procedures were listed which midwives considered vital to the well-being of their occupation and their clients: the right to use forceps in an obstructed head delivery and to stitch a simple rupture of the perineum. The ruling of the medical law of 1865 , still the point of reference, which prohibited midwives the use of instruments was, they argued, hopelessly out of date and bore no relation to standards of training. Reviving a complaint made in 1904, they spoke of wanting the right to put what they had learnt into practice, and of being only equipped to do half their job: "the midwife is a half force". 55

They went on to give a hypothetical case where a well-qualified midwife struggled for one or two days with a difficult, prolonged "normal", birth, yet one which, as the midwife was well aware, would require a forceps extraction. The midwife had to let the woman struggle on, in order that the cervix be properly dilated, and ready for the forceps to be applied. The midwife then had to decide on the precise moment to call for the general

51 AVA, 442. 'Stukken betreffende behandeling van het vroedvrouwen vraagstuk, met name de verlenging van de opleiding en uitbreiding van de bevoegdheden, 1904-15'. Brief van de

Hoofdbestuur van Bond van Vrouwelijke

Verloskundigen aan Minister Binnenlandsche Zaken, 12 Dec. 1904 (no. 10410).

52 Ibid., 442. Centrale Gezondheidsraad, Afd. BB. Bericht op 14 Dec. 1904, betr. adres Bond van Vrouwelijke Verloskundigen, 10 March 1905 (no. 888/7).

\footnotetext{
53 Rigter, op. cit., note 40 above, p. 90.

54 Archief Centrale Gezondheidsraad 1902-20. Voorstellen en Verslagen, 1905, 'Inlichtingen en raadgevingen aan vroedvrouwen', opgemackt door de commissie van praeadvies (no. 8).

55 AVA, 442. 'Stukken betreffende behandeling van het vroedvrouwen vraagstuk, 1904-15'. Adres aan den Minister v. Binnenlandsche Zaken betr. verbetering van de positie en opleiding van de vroedvrouwen met toelichting, 22 Sept. 1910.
} 


\section{Questions of Competence: The Midwife Debate in the Netherlands}

practitioner to deliver the woman, in scattered rural areas no easy matter. Not too early or the woman could be torn, but not too late or the mother or child could be in danger. If, argued the Bond spokeswomen, midwives could perform the procedure themselves it would save much uncertainty and result in a better outcome for mother and child. The skill lay not in performing a forceps extraction, but in deciding at which point this was necessary. After a woman had suffered many hours with the midwife in attendance, the doctor would arrive, "quickly apply the forceps and deliver the child inside a quarter of an hour". What, the midwives asked, would be made of this? Would the woman not believe that the midwife had tortured her unnecessarily for many hours-perhaps to try to save her reputation and her fee-while the doctor was her salvation? Could the woman be made to believe the midwife's account that all her pain had been a necessary preparation? Or would opinion turn against the midwife: "If only we had fetched the doctor; the woman is completely worn out; people choose a midwife because she is cheaper-but never again a midwife". This, the Bond spokeswomen argued, would carry the risk that in a similar situation the forceps would be applied too soon. ${ }^{56}$

The address added that because the midwife did nothing else beside attend deliveries and care for the newborn, she was far better equipped for midwifery than the doctor, who always carried the risk of infection with him. The midwife petitioners also grumbled about their incomes and unfair competition, but the thrust of their demand was for proper competence to carry out their work of attending "normal" deliveries. ${ }^{57}$ The Centrale Gezondheidsraad who had been brought in to respond to the midwives' address, simply referred back to the memorandum of 1905 which declared that it would be "dangerous" to extend midwives' competence. ${ }^{58}$ The committee set up by the Raad did not want to discuss the issues and simply dismissed the midwives' demands. Showing a distinct lack of originality, they advised the government to take more action against unqualified practice and urged midwives to work together in unions to raise their fees. ${ }^{59}$

Although at no point was there talk of reducing the role of midwives, the position in 1911, when a second report on their standing and future was drawn up, did not look promising. The second report showed an apparently unbridgeable gap between the opinions of midwives and doctors about standards of practice and their respective tasks, mingled with strong financial interests. Many of the demands made in the earlier report of $1897,{ }^{60}$ to get rid of the unqualified and not to compete too vigorously with the midwife, were simply reiterated in 1911.61 On the whole, however, the general practitioner respondents were more positive about the abilities of midwives to carry out their work. ${ }^{62}$ No doubt related to real improvements in training, 80 per cent believed the skills of midwives to be "good" or "very good" compared with 60 per cent in $1897 .{ }^{63}$ The Centrale Gezondheidsraad also produced its own muted response to the 1911 report, recommending that the training period of midwives be extended to three years and

56 Ibid., pp. 5-6.

57 Ibid.

58 Ibid., Centrale Gezondheidsraad, Afd. VA. Betr. vroedvrouwen, 26 Oct. 1910 (no. 1571/2); Betr. adres Bond van Nederlandse Vroedvrouwen, 21 April 1911 (no. 578/2).

${ }^{59}$ Rigter, op. cit., note 40 above, pp. 90-1.
60 'Rapport', 1897, op. cit., note 13 above.

61 'Rapport', 1911, op. cit., note 13 above.

62 Van Lieburg and Marland, op. cit., note 3 above, pp. 312-13.

63 'Rapport', 1897, op. cit., note 13 above, p. 612; 'Rapport', 1911, op. cit., note 13 above, pp. $1130-1$. 


\section{Hilary Marland}

refresher courses introduced. On the question of competence, the Raad again merely referred back to earlier recommendations. ${ }^{64}$

Only fifteen years had passed since the drawing up of the first report, but in these years much had changed. The committee compiling the 1911 report included representatives of the Nederlandsche Gynaecologische Vereeniging (Dutch Gynaecological Society), Professor G C Nijhoff, professor of obstetrics and gynaecology in Groningen, Klaas de Snoo, head of the Rotterdam school, and Catharine van Tussenbroek, the ardent midwife supporter. ${ }^{65}$ Meinart Niemeijer, a general practitioner and an editor of the midwives' journal, was also on the committee, and the health inspectorate was represented. General practitioners still completed the questionnaires, but there was scope for a reinterpretation of their answers by the reporting committee. But perhaps because de Snoo was responsible for the actual compilation of the report, its conclusions were modest, suggesting little and achieving less in the way of change. Van Tussenbroek was highly dissatisfied with the outcome and suggestions of how to make the midwives' position "tolerable"; the midwife "on top of her exhausting, because heavily responsible, position, ... must face financial uncertainty, together with a poor future". ${ }^{66}$

Following the flurry of activity in drawing up the two reports of 1897 and 1911, general practitioners faded somewhat out of the debate. Their interests did not get much attention, and they were poorly represented on Raad committees. Some clearly felt badly done by. In a minority report of 1919 referring to plans to encourage the midwife to attend newborn babies, Th G den Houter, a Raad member and Chief Inspector of the State Health Inspectorate, associated the midwife question with the doctors' decline to a "medical proletariat". ${ }^{67}$ On the other hand, by this time many doctors seemed to be establishing a modus vivendi with midwives, keeping a portion of midwifery work for themselves, though not always the best paid, with midwives cornering much lucrative urban practice. ${ }^{6}$ Despite a massive increase in the number of general practitioners3,000 in 1908 compared with 1,009 in 1895-midwives held their own. Their numbers also rose steadily, from 830 in 1895 to 950 in $1925,{ }^{69}$ and they were still delivering around 60 per cent of babies. ${ }^{70}$ By 1924 a breakdown of obstetric work claimed that all 2,490 general practitioners were attending deliveries. Some 63 per cent were present at fewer than 60 births per year, but 15 per cent attended between 60 and 150 births annually, a good deal of midwifery work. Most of the 972 midwives recorded were attending up to 100 deliveries a year, but almost 20 per cent delivered between 100 and

64 AVA, 442. 'Stukken betreffende behandeling van het vroedvrouwen vraagstuk, 1904-15'. Centrale Gezondheidsraad, Afd. VA. Aan den Minister van Binnenlandsche Zaken, betr. vroedvrouwenvraagstuk, 14 June 1912 (no. 627/7).

${ }^{65}$ Ned. Tijdschr. Verlosk. Gynaecol., 1909, 18: 337-8. p. 215 .

66 Van Tussenbroek, op. cit., note 10 above,

${ }^{67}$ AVH, la. Vergaderstukken van de Gezondheidsraad, 1920-30. Nota van minderheid aan Minister van Arbeid, 's-Gravenhage, 23 May 1919.

\footnotetext{
${ }^{68}$ Marland, op. cit., note 11 above.

69 Provincial and state medical registers; AVA, 442. 'Stukken betreffende behandeling van het vroedvrouwen vraagstuk, 1904-15'. Brief aan Minister Binnenlandsche Zaken van E van der Werff, J Veenhof en T Jonk-Hartman, 22 Sept. 1910 (no. 4953); AVH, la. Vergaderstukken van de Gezondheidsraad, 1920-30. Staatstoezicht op de Volksgezondheid, betr. plaatsing leerlingen op de kweekscholen voor vroedvrouwen, 23 May 1927 (no. 363/3863.1).

${ }^{70}$ Van Tussenbroek, op. cit., note 10 above, p. 183.
} 


\section{Questions of Competence: The Midwife Debate in the Netherlands}

150 babies a year, and many over $200 .^{71}$ The complaints and sometimes vitriolic exchanges between midwives and general practitioners, common at the turn of the century, became less evident in the 1910 s and 1920 s. $^{72}$ Many general practitioners, meanwhile, were pushing hard to get more midwives into the countryside, where there were acute shortages of doctors and midwives. ${ }^{73}$

Midwives, meanwhile, had been greatly stimulated by the setting up of the Tijdschrift voor Praktische Verloskunde ("in the service of the midwife") following the first report on midwives' status in 1897. Though the editorship remained firmly in the hands of the doctors who had initiated it, the Tijdschrift gave midwives a platform where they could air their grievances, ask questions, and raise issues. It also served as a mouthpiece of the Bond, which in the early years of the century grew enormously in numbers and organization, attracting the support of more than one-third of midwives. In 1914 the Bond received royal status despite the protests of the medical associations. ${ }^{74}$ Midwives, now vigorously defending their occupation, were petitioning the government regularly about their conditions of work, extensions of their competence, and for a clarification of their working relationships with doctors. It is also of significance that their opinions were now being actively sought, and the 1911 report included a separate questionnaire to be completed by midwives. Not surprisingly, where the questions did overlap with those asked of the general practitioner respondents, the answers were very different. Some 67 per cent of midwives completing the questionnaire believed that their competence should be extended, compared with 11 per cent of doctors. They saw the right to use forceps, to stitch the perineum and to give injections as being crucial to the well-being of their practices and their clients. ${ }^{75}$

\section{A Change of Approach in the "Midwife Debate" 1920-32}

A period of quiet followed the 1911 report regarding the discussion of midwife issues in the Centrale Gezondheidsraad and journal literature. Yet within a decade a shift can be detected in the way the midwife question was being approached and in attitudes towards the midwife. The Raad began to listen more to what the midwife was asking for and why, and the difficulties the midwife faced in practice in staying within the letter of the law. Vague pleas asking midwives to band together and general practitioners to behave themselves, and suggestions of how to eliminate the unqualified, were replaced by concrete recommendations, which tended increasingly to favour the midwives' demands. The idea of "unfairness" focused increasingly on competence rather than the notion of p. 3978 .

71 Van der Hoeven, op. cit., note 20 above,

72 Marland, op. cit., note 11 above.

73 This was especially the case in the south. P A Barentsen was keen to recruit midwives in the struggle to rid the villages of North Brabant of traditional and dangerous childbirth practices, and he was not alone in this. P A Barentsen, 'Over de kindersterfte ten plattenlande van Oost-

Noordbrabant', Ned. Tijdschr. Geneesk., 1922, 66(2): 610-22. See Marland, note 18 above, both articles.

\footnotetext{
74 AVA, 443. 'Stukken betreffende bezwaren tegen de koninklijke goedkeuring van de statuten van de Nederlandsche Maatschappij tot Beharting de Berlangen van Vrouwelijke Verloskundigen te Amsterdam, 1914'. The Dutch Society for the Promotion of Medicine was only granted royal status in 1949.

75 'Rapport', 1911, op. cit., note 13 above, pp. $1130-1,1157$.
} 


\section{Hilary Marland}

midwives and general practitioners battling it out in the towns and villages. The answer to the midwives' problems turned not on the fact that general practitioners were there and practising midwifery, but on their entitlement to use procedures which were giving them the edge in attracting clients. The rules were to be changed, giving midwives the ability to join in a fair fight for clients.

This change was no doubt related to the major shake up in the Raad following the Health Act of 1919, when it lost its executive powers. After 1920 the Raad's task became a purely advisory one. The staff of health inspectors and civil servants was replaced by a small core committee and a larger number of co-opted advisors, drawn from a wide range of backgrounds and professional groups. Paradoxically, this apparent loss of power served to strengthen the Raad. No longer combining advisory work with management, its function became clearly focused and the recommendations of its committees more independent. The Raad came under the energetic steermanship of N M Josephus Jitta, chairman from 1919 to 1940, and as such responsible for calling together the advisory committees. ${ }^{76}$ The Raad was requested to give advice on scientific matters, but also tackled many issues related to public health, social medicine, ethics and professional matters, with contagious disease prevention and medical practice predominating. ${ }^{77}$

The question as to whether the midwife's training equipped her to carry out certain obstetric procedures was discussed in great detail. In 1920 in one of the last acts of the old Centrale Gezondheidsraad, legal action was encouraged to improve the position of the midwife, "through a limited enlargement of her competence", ${ }^{78}$ in a vague document which, however, indicated that a turning point was being reached. In 1921 the period of training in the state schools was extended from two to three years, the last year to include more practical schooling and infant care. The Raad had first recommended this step in 1912. In 1924 , on the advice of the Raad, a more fundamental change took place. It was ruled that the midwife was still to call for the help of a doctor in difficult cases, but, if none was available, then the midwife was allowed "to undertake artificial manoeuvres so long as no instruments were employed", and she was enabled to give specified medicines post-partum, including derivatives of ergot, to stop haemorrhaging after the delivery of the placenta. ${ }^{79}$

In 1930 there was a re-run of the scenarios of 1904 and 1910, when the Bond and the Roman Catholic midwives association petitioned the government to reconsider two articles of the Health Act of 1865 which prohibited midwives from using medicine during deliveries. Concern was expressed that the use, for example, of drugs to reduce the length of labour was going to lead more women to turn to doctors and to squeeze out the midwife. The Bond spokeswomen demanded the right to supervise pregnancy from thirtytwo weeks onwards, to give injections to stimulate contractions, and pituitrin to speed the delivery of the placenta. All this was necessary to prevent a decline in public faith in the midwife, so vital in providing "good midwifery help" for the population. Lastly, they demanded official recognition of the midwives' task in attending healthy babies. ${ }^{80}$

76 Rigter, op. cit., note 40 above, pp. 310-12.

77 Ibid., pp. 73, 346.

78 Jaarverslag van het Staatstoezicht op de Volksgezondheid, 1920, pp. 148-9. Cited ibid., p. 91 .

79 Verslagen en mededeelingen betreffende de volksgezondheid, 1925, pp. 273-4; AVH, la.

\footnotetext{
Vergaderstukken van de Gezondheidsraad, 1920-30. Nederlandse Staatscourant, 29 Sept. 1924 (no. 189).

80 AVH, 13. Gezondheidsraad 1930-31. Brief aan de Gezondheidsraad van S Sievertsen Buvig, A J de Graaf van der Elst, C Stoffers and C $\mathbf{H}$ v d Linden de Groot, Amsterdam, Jan. 1930; Vox Med., 1930, 30: 71-2.
} 


\section{Questions of Competence: The Midwife Debate in the Netherlands}

The petition was referred to the Raad, who appointed a committee to look at a range of questions connected to midwives' competence. The minutes of the meetings express a wide and complex range of views, and the deliberations were to last many months. Opinions and alliances changed as the debate shifted from medical to social issues. While some committee members, like de Snoo, were happy to give midwives a larger role in antenatal care and during the lying-in period, they were fundamentally opposed to their involvement in difficult deliveries and to their use of drugs of any kind. ${ }^{81}$ The question of permitting the midwife to use pituitrin raised much controversy. The midwives' representative, Mej. Sievertsen Buvig, supported by Meurer, found this essential. Other committee members believed that there was nevver such a rush that the midwife could not wait for the doctor to arrive. Jitta, who chaired many of the meetings, was impressive in steering the proceedings, making canny suggestions for compromise and amendments which leaned towards an extension of midwives' competence. Though an "old-fashioned liberal" who wanted to note the opinions of all his committee members, those voices that he did not wish to hear were put "on the sidelines" 82 On the subject of pituitrin he was not opposed to giving permission provided that there was a good clear ruling. The vote was finally divided $5 / 4$ in favour of allowing midwives to use pituitrin under strict conditions. ${ }^{83}$

It is impossible to talk of hard and fast divisions in the Raad; within all the groups represented opinion was divided. Amongst the obstetricians, de Snoo continued to produce reams of evidence opposing any extension of midwives' competence long after questions had been decided, ${ }^{84}$ while Meurer was constantly pushing for change. The middle ground was occupied by individuals such as Nijhoff, the Groningen professor of obstetrics. In 1930 he drew up a report on midwives' activities, showing that in many cases they went beyond their competence as defined in law, delivering breech births, second sets of twins, using pituitrin, applying forceps. He found much evidence of this, was anxious about it, but concluded, quoting from the midwives he spoke to, that they had little choice in practice, when "the doctor came too late", "the doctor always tells me to do the delivery myself", or "I have done this procedure so many times before" ${ }^{85}$

In 1931, following a long and drawn-out discussion, the committee of the Gezondheidsraad composed a recommendation. Riddled with conditions and carefully worded, it, in effect, supported the midwives' demands, and even added procedures not referred to in their petition of January 1930. Midwives were authorized to give advice and assistance to pregnant women in the second half of pregnancy, considerably longer than the post-thirty-two weeks which midwives had asked for; they were enabled to correct malpresentations externally; to take measures against sickness in pregnancy under the directions of a doctor, and to give specified medicines orally or through injections in cases of bleeding and weak contractions. The advice of the Raad passed into law in $1932 .{ }^{86}$

81 Ibid., Commissie inzake bevoegdheid vroedvrouwen, 26 Nov. 1930.

${ }^{82}$ Rigter, op. cit., note 40 above, p. 348.

83 AVH, 13. Gezondheidsraad 1930-31. Commissie inzake bevoegdheid vroedvrouwen, 26 Nov. 1930.

\footnotetext{
84 Ibid. Brief van K de Snoo, 17 Jan. 1931.

85 Ibid., No. 153/15. Betr. uitbreiding bevoegdheid vroedvrouwen, 26 May 1930.

86 Verslagen en mededeelingen betreffende de volksgezondheid, 1934, pp. 395-411.
} 


\section{Hilary Marland}

Paralleling the steady extension of their competence since 1920, midwives also began to be seen increasingly in the light of agents in the campaign to reduce infant deaths and to care for mothers during pregnancy and post-natally. Twenty years into the Dutch infant welfare campaign, doctors and the staff of the infant welfare clinics (consultatiebureaus) were becoming increasingly aware that they were unable to reach all those who needed help, especially in rural districts. ${ }^{87}$ The issue of recruiting the midwife to the cause burst to prominence in the early 1920 s, with a good deal of discussion taking place in the medical press and the Raad. ${ }^{88}$ The midwives' schools were already deeply involved in providing infant welfare clinics and mothercraft courses, ${ }^{89}$ and the discussion was partly stimulated by the plan of the Rotterdam midwives' school to attach a clinic to its premises. A few Raad members feared for the position of the general practitioner, but the majority, including the school directors, supported the extension of midwives' work to cover the care of healthy babies. The majority preferred the midwife above the "unknown" nurse; the minority wanted the nurse to attend infants, supervised by the doctor, rather than have the midwife act independently. ${ }^{90}$ It was also suggested that the functions of midwife and maternity nurse be combined, though there was concern about what this would mean for the standing of the midwife. One viewpoint was that nursing better-off clients would be a safer bet than infant care, which tended to be concentrated amongst poorer families. ${ }^{91}$ The extension of training in 1921 marked an acceptance of the midwives' broader role, and an infant clinic opened in connection with the Rotterdam school in 1922. The role of the midwife in infant care and maternity nursing, however, remained ambiguous, despite repeated demands for clarification.

In many cases market issues stepped in to force events. Many midwives could not support themselves by delivering babies alone and were forced to take up maternity nursing to survive in practice. Some had a double or even triple function in their towns and villages, acting as midwife, maternity nurse, and infant welfare worker. Others expanded their antenatal activities. There was an enduring need for these services, and for this method of making midwifery profitable, or at least ensuring a living wage for midwives. In 1937 the Wit-Gele Kruis ${ }^{92}$ in Wageningen was eager to get a Catholic

87 The first consultatiebureau was set up in The Hague in 1901 , by 1916 there were 14 bureaus, in 192547 , and by 1929 , following the introduction of government subsidies, 246. See Marland, op. cit., note 15 above, pp. $80-1$.

${ }^{88}$ For example, the Ned. Tijdschr. Geneesk, published a number of articles in 1921 on the subject, including $\mathrm{R} \mathbf{J}$ Th Meurer, 'Vroedvrouw en zuigelingenzorg', Ned. Tijdschr. Geneesk., 1921, 65(1): 338-43, which was followed up by a lively debate.

${ }^{89}$ In 1920 the staff of the Heerlen school saw over 231 infants at its clinics (898 consultations) and taught a total of 18 mothercraft courses in local towns. It was regretted that they had not got the means to carry out infant consultations in the mothers' own homes. Bg17CIII. Wilhelmina Kweekschool voor Vroedvrouwen te Heerlen. 8e Jaarverlsag, 1 Jan.-31 Dec. 1920, p. 48.

\footnotetext{
90 Verslagen en mededeelingen betreffende de volksgezondheid, 1922, pp. 501-3.

91 AVH, la. Vergaderstukken van de
} Gezondheidsraad, 1920-30. Afschrift. Staatstoezicht op de Volksgezondheid, betr. vestiging van vroedvrouwen afkomstig van de Rijkskweekscholen voor Vroedvrouwen, 24 March 1923 (no. 149/3340).

92 The "Cross societies" were private organizations set up to provide services in preventive medicine, including infant welfare clinics, maternity nursing, health education, and tuberculosis control. Those insured with the societies could book a midwife gratis or for a modest fee. Cross societies were organized along denominational lines, the Wit-Gele Kruis being a Catholic organization. See A Querido, De Wit-Gele vlam. Gedenkboek ter gelegendheid van het 50-jarig bestaan van de Nationale Federatie het Wit-Gele Kruis 1923-1973, Tilburg, Nationale Federatie het Wit-Gele Kruis, 1973. 


\section{Questions of Competence: The Midwife Debate in the Netherlands}

midwife to the village, but had great difficulty making a financially viable offer. Only by putting together a complicated package, with separate charges for maternity nursing, plus free insurance and bicycle, could the society's officers succeed in attracting Mej. Zeestraten to the position. Cornelia Huyboom, a midwife working in North Holland in the 1930s described how, with few deliveries to keep her busy, she organized an antenatal clinic in her own home, investing in equipment to measure blood pressure and scales. Those who preferred it were visited at home. Because there was no infant clinic in the district, she was often called upon to give advice on feeding. ${ }^{93}$ In 1946, Theresia van Krieken, who practised in Helmond, reported that in the previous year she had delivered 80 women. She anticipated having more midwifery work in the current year, but "to fill my days I do some nursing here and there as well, which is not unpleasant work". 94

\section{Conclusion}

New rulings could not eliminate the yawning gap between Raad discussions and legislation and the reality of midwives' practices. As the pages of the midwives' journal testify, the midwife faced enormous problems keeping within the letter of the law, as she waited for the doctor to arrive. Time and again the anxieties of midwives are recorded, when the woman they had delivered needed stitches, or when called to cases of threatened miscarriage but legally not being able to intervene. ${ }^{95}$ Yet this gap was narrowing with the passing of legislation, a steady extension of midwives' competence, and in terms of the ways they were being perceived as agents of public health. Many wanted a broader role for the midwife in offering maternity care. In 1930 the Bond spokeswomen emphasized that the "time lies far behind us, when obstetric help began at the same time as the birth and ended when this was completed". 96 One year later, Dr Meuleman of the Heerlen school, concluded that the work of the midwife had changed significantly since the beginning of the century. "The midwife's work is, after all, nowadays no longer complete with the taking on and supervision of a delivery ... There also rests on her a heavy social task", which included antenatal care, watching for abnormalities of pregnancy, and striving to improve standards of hygiene among the families she attended. ${ }^{97}$

The law of 1932 by no means marks the end of the story. By 1940 midwives were once more pushing for a further extension of their competence. In 1941 overwhelming support was accorded to the midwife, when the Ziekenfondsen (health insurance societies) gave midwives a monopoly over normal obstetrics. ${ }^{98}$ Though the debate continued, just as the legislation of 1818 and 1865 ensured midwives' right to work as normal birth attendants, it appears that the first three decades of this century, which saw a peak in the discussion of the midwife's tasks, were crucial to ensuring her survival under changing practice conditions.

93 AVH, 187. Geslaagde Vroedvrouwen, Cursus 1933-36: S C Zeestraten; C A Huyboom.

94 AVH, 192. Geslaagde Vroedvrouwen, Cursus 1938-41: T C van Krieken.

95 For example, Maandblad voor Praktische Verloskunde, 1897, 1: 6, 26; Geneeskundige Gids, 1930, 8: 644-9, 661-6.
96 AVH, 13. Gezondheidsraad 1930-31. Brief aan de Gezondheidsraad, Jan. 1930.

97 Limburgsch Dagblad, 24 Dec. 1931.

98 Eva Abraham-van der Mark, 'Dutch midwifery, past and present: an overview', in idem (ed.), op. cit., note 3 above, pp. 141-60, on pp. 146-8. 


\section{Hilary Marland}

These conclusions beg the question as to why the Dutch midwife fared so well when during the same period her counterparts in other countries were being eliminated, were loosing status, clients and income, or were being controlled under conditions not of their choosing? This essay can only suggest reasons for this success. Laws to regulate the midwife's practice, to license her, define her tasks and to train her, dated back to the early nineteenth century. But other countries also introduced midwife regulation and training at an early date-France, Belgium, Germany, the Swiss Cantons, Denmark and Sweden. ${ }^{99}$ The Dutch midwife continued to carry out a large proportion of deliveries, around 58 per cent in 1910, but even in the United States 50 per cent of births were midwife attended in the same year. ${ }^{100}$ The number of midwives increased steadily in the Netherlands between the late nineteenth and early twentieth centuries, but this again was not unusual. In neighbouring Belgium legislation tracked that of the Netherlands. In 1818 Belgian midwives were included in legislation to control medical practice, being authorized to carry out normal deliveries, a competence confirmed in a law of 1885 . Schools were established for midwives, and their numbers grew, from 1,946 in 1875 to 2,503 in 1900, though in relation to the population the rate remained fixed at 3.6 per 10,000 inhabitants. ${ }^{101}$ These figures were considerably higher than those for the Netherlands in 1895, with its 830 midwives, 1.7 per 10,000 inhabitants. ${ }^{102}$ Yet in Belgium opposition to the midwife by general practitioners was strong; midwives were accused of pushing up infant deaths, excluded from public health work, and doctors moved in on midwife practice in the countryside. ${ }^{103}$

One important factor in the Netherlands was that the number of deliveries attended by midwives remained high and constant. Midwives were attending an average of 110 deliveries in 1910. ${ }^{104}$ This compared with estimates of half this number in Germany and Norway, 67 in France and between 36 and 52 in England. ${ }^{105}$ The support of obstetricians, ranging from the accepting to the enthusiastic, also seems to have been a crucial factor in determining the midwives' well-being, as was the very low level of institutional obstetrics, with the Netherlands missing out on the rapid growth in hospital deliveries between 1900 and the 1930s. Many medical practitioners made it their mission to improve obstetric care and reduce maternal and infant mortality, with the midwife as the pivotal point of the services. A steady rise in school-trained midwives and ever-improving standards, midwives' own campaigning activities, and the levelling off of competition between general practitioners and midwives, also colluded in securing the midwife's position.

\footnotetext{
99 See Loudon, Death in childbirth, op. cit., note 31 above, pp. 402-27; Matthew Ramsey, 'The politics of professional monopoly in nineteenth-century medicine: the French model and its rivals', in Gerald L Geison (ed.), Professions and the French State, 1700-1900, Philadelphia, University of Pennsylvania Press, 1984, pp. 225-305.

100 Klinkert, op. cit., note 5 above, p. 72; Kobrin, op. cit., note 2 above, p. 350.

${ }^{101}$ Rita Schepers, De opkomst van het medische beroep in Belgie. De evolutie van de wetgeving en
}

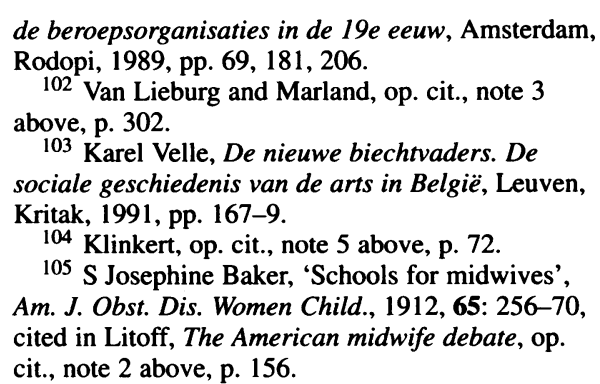




\section{Questions of Competence: The Midwife Debate in the Netherlands}

Of the greatest importance was the growing realization that the midwife needed to tack the extra elements of maternity nursing and infant hygiene to her obstetric work to make her practice viable. The claim that there is, and always has been, a rigid division between nursing and midwifery in the Netherlands is in this sense a myth. ${ }^{106}$ In the early twentieth century many women held both nursing and midwifery diplomas, and most midwives would include, at the very least, a little maternity nursing and infant care in their practices. At the same time, it was realized that as the face of obstetrics was changing with the adoption of new techniques and medicines, the midwife's competence had to be extended to give her the potential to survive. The definition of the midwives' work in "normal" cases of childbirth was throughout the discussions a sliding one. Above all, the debate in the Raad shows the complexity of the issues affecting obstetric practice in the early twentieth century, and the divisions within many interest groups. In the Dutch case, this was much more than general practitioners moving in on midwifery work, obstetricians keen to monopolize, and midwives losing out in the face of increased "medicalization". The midwife was able to keep to her main task of providing attendance in normal childbirth, but at the same time was able and keen to adapt to the changing face of midwifery work.

106 This conclusion has been based on the fact that nurses and midwives received and still receive a distinct training, but the realities of practice earlier this century have not been examined. See, for example, the conclusion of Beatrijs Smulders and Astrid Limburg, 'Obstetrics and midwifery in the Netherlands', in S Kitzinger (ed.), The midwife challenge, London, Pandora Press, 1988, pp.
233-47, on pp. 237-8: 'The midwife is no nurse'. Nanny Wiegman, who is working on the history of nurse training and practice during the late nineteenth and early twentieth centuries in the Netherlands has observed that many women entering nurse training also held midwife diplomas. Personal communication with Nanny Wiegman, August 1994. 